Volumen 16 Número 3, Julio - Septiembre 2021, pp. 1-21, e632

THE ECONOMICS AND FINANCE EFFECTS OF THE COVID-19 PANDEMIC Editor: Dr. Ignacio Perrotini

DOI: https://doi.org/10.21919/remef.v16i3.632

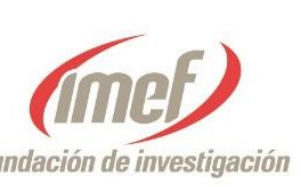

(Received: March 22, 2021, Accepted: June 28, 2021.

Published: June 30, 2021)

\title{
COVID-19 Pandemic Initial Effects on the Idiosyncratic Risk in Latin America
}

Andre Assis de Salles ${ }^{1}$ - Federal University of Rio de Janeiro, Brasil

This work aims to estimate the idiosyncratic risk of Latin American economies and emerging economies using heteroscedastic conditional models to verify the impact of the Covid-19 pandemic on the risk associated with productive projects. The methodology used is based on the portfolio theory to estimate the idiosyncratic risk. The results highlight that Latin American economies are more susceptible to sanitary crises, such as the current pandemic, than emerging economies. The inability of emerging countries to generate the necessary savings to provide for their development imposes the need to attract resources for project financing and investment. Thus, determining the specific risk of Latin American countries is fundamental for international investors giving them another parameter when deciding on investment or financing on the continent. Originally, this work demonstrates how the sanitary crisis deriving from the Covid-19 pandemic affected the idiosyncratic or specific risk of Latin American economies using their capital market indicators. This study contributes to the assessment of Latin American economies specific risk or country risk at the beginning of the pandemic.

JEL Classification: C22, F36, G01, G12, N26.

Keywords: Covid-19 Pandemic, Idiosyncratic Risk, Latin American Economy.

\section{Efectos iniciales de la Pandemia por COVID-19 sobre el riesgo idiosincrático en América Latina}

Este trabajo tiene como objetivo estimar el riesgo idiosincrásico de las economías latinoamericanas y las economías emergentes utilizando modelos condicionales heterocedásticos para verificar el impacto de la pandemia Covid-19 sobre el riesgo asociado a los proyectos productivos. La metodología utilizada se basa en la teoría de la cartera para estimar el riesgo idiosincrásico. Los resultados destacan que las economías latinoamericanas son más susceptibles a crisis sanitarias que las economías emergentes. La incapacidad de los países emergentes para generar los ahorros necesarios para su desarrollo, impone la necesidad de atraer recursos para la financiación e inversión de proyectos. Así, determinar el riesgo específico de los países latinoamericanos es fundamental para los inversores internacionales dándoles un parámetro más a la hora de decidir sobre inversión o financiación en el continente. De manera original, este trabajo demuestra cómo la crisis derivada de la pandemia Covid-19 afectó el riesgo idiosincrásico o específico de las economías latinoamericanas utilizando sus indicadores del mercado de capitales. Este estudio contribuye a la evaluación del riesgo específico o riesgo país de las economías latinoamericanas al inicio de la pandemia.

Clasificación JEL: C22, F36, G01, G12, N26.

Palabras clave: Covid-19, Riesgo Idiosincrásico, Economías Latinoamericanas.

1 Corresponding author. Email: aadesalles@gmail.com

* No source of funding for research development 


\section{Introduction}

The sanitary crisis caused by the Covid-19 pandemic is compared to the 1918 crisis caused by the H1N1 influenza pandemic. The sanitary crisis that triggered the Covid-19 pandemic began with news of a public health problem that started in Wuhan, capital of Hubei province in China, caused by a virus identified as SARS-CoV-2, a new Coronavirus, which quickly spread over 180 countries causing high mortality. Compared to the 1918 crisis caused by the H1N1 Influenza pandemic that haunted humanity at the beginning of the twentieth century. The Covid-19 pandemic has also triggered many studies and research in the most diverse areas of knowledge.

The great crises repercussions that spread throughout the world during the last centuries have been the object of studies and researches over time. Most of these researches were aimed to verify the instantaneous effects and the influence of these crises on the world population welfare and the economic and social behavior and relations in the world. Among these researches, Mackellar (2007) can be mentioned. In a broad study on the economic impacts of the Influenza pandemic, Mackellar (2007) highlights that the loss is more human than material. The economic impacts of this pandemic, according to Mackellar (2007), can be classified as direct and indirect. The study includes hospital costs, lost days of work, medicine costs, the decrease in tax revenue, and the increase in health and economic aid expenditures to sectors in difficulty. Followed by government fiscal deficits as direct impacts. Among the indirect economic impacts, Mackellar (2007) includes the economic multiplier effects of direct costs and the behavior of consumers, affecting consumption relationships.

The crisis caused by the Covid-19 pandemic had a direct impact on social and economic relations in all regions of the world affecting national economies and the world economy as well as the world financial markets. These financial markets signal the expectations of national economies and the world economy, through money, foreign exchange, credit, and capital markets. While in the public health area, efforts are being made to minimize the serious problems in public health systems, economic agents seek to verify the problems that the Covid-19 pandemic has caused and should cause in the years to come, with the growing disorder in the costs and the production chains.

The financing and investment of production in economies happen through the financial market, in particular via the capital market. The productive projects that provide the necessary infrastructure for the development of economies and maintenance of jobs and the income growth have in the capital market the source of resources for investments and financing. In this way, one of the important advanced indicators of the economy is the performance of the capital market, whose first indicator is the stock market profitability index. This index reflects the expectations of economic agents regarding the economy and allows estimates of the volatility or risk associated with productive projects, sectors of national economies, a national economy, and the global economy. The volatility or the total risk has two components, the market risk, and the idiosyncratic or unique risk. The market risk refers to the risk of exposure of productive projects, sectors of national economies, and a national economy, to the behavior of the respective market portfolios, respectively, the sector project portfolio associated with the productive project concerned, the portfolio that represents the national economy, and the portfolio that represents everything that is produced in all national economies. The idiosyncratic risk is the unique risk associated only with a specific productive project 
or the project portfolio of a sector, or of a sector of a national economy, or a national economy. Thus, each national economy has as an indicator that represents the portfolio that encompassed most of the productive projects of each of the national economies, that is, the indicator closest to a market portfolio which is the equity market profitability index of each national economy. These economies are part of the world economy which has a profitability index of the global stock market as a proxy for the market portfolio. Some agencies or market institutions calculate and make available some profitability indexes of the nationals and global stock markets.

Many studies and researches started with the objective of verifying and mitigating the pressing public health and economic problems that present themselves during the Covid-19 pandemic and the possible problems that will be originated. Among these studies it must be mentioned: Naidenova et al. (2020), which deals with idiosyncratic and systematic shocks caused by pandemics in financial markets; Gaurinchas (2020), who discusses the economic impact of the Covid19 pandemic; the study by Şenol and Zeren (2020), which deals with the influence of the Covid-19 pandemic on the global economy through the capital market using the global market share profitability index to study the long run relationship between the markets of actions and the effects of the Covid-19 pandemic; the research by Zeren and Hizarci (2020), which deals with the influence of the Covid-19 pandemic in the capital markets of selected countries; the work by Alam et al. (2020), which presents a study on the effect of the lockdown period on the Indian capital market through a sample of 31 companies listed on the Bombay Stock Exchange; and other researches related to this topic, such as Pata (2020), Khanthavit (2020), Atkeson (2020), Barro et al. (2020), Anderson et al. (2020) and Mckibbin and Fernando (2020).

Regarding the risk, based on the seminal work of Sharpe (1963) many studies have been carried out seeking in an appropriate way to determine the total risk and its components: systematic risk and idiosyncratic risk. The estimation of the market model, or the Single Index Model, suggested by Sharpe (1963) allows the determination of the main indicator of market risk, the beta coefficient, and the idiosyncratic risk also called specific risk or unique risk. In a pioneering work, Rosenberg and McKibben (1973) seek to forecast the systematic risk and the specific risk of stocks and propose stochastic models for determining the beta coefficient and the idiosyncratic risk using the Single Index Model. From this work, many studies were developed. Fu (2009) estimated the idiosyncratic risk and its relationship with the monthly stock returns using the three-factor model, suggested by Fama and French (1993). Besides that, Fu (2009) employed some of the ARCH family for volatility models derived from the Autoregressive Conditional Heteroscedasticity Models available in the finance literature developed from the seminal work of Engle (1982) and the work of Bollerslev (1986). In another relevant work, Angelidis and Tessaromatis (2008) note that the idiosyncratic risk has been neglected to the detriment of a greater emphasis given to the systematic or market risk in determining the risk premium. Sequentially, Campbell et al. (2008) emphasized the importance of assessing specific or idiosyncratic risk. In general, market volatility increases in the periods leading up to these crises and during crisis periods, as observed by Kalra (2008) in the recent period of the world economy with the subprime crisis. Among the most recent studies that attempt to estimate idiosyncratic risk, it can be mention Blitz et al. (2020) which deals with this risk as an anomaly can be mentioned, Chang et al. (2018) with data from the Japanese economy, and Shi and Zhou (2019) that verify the idiosyncratic risk of the Chinese stock market. 
This work aims to estimate the idiosyncratic risk or unique risk of the Latin American economies and the emerging economies using heteroscedastic conditional models of the ARCH family models to verify the impact of the Covid-19 pandemic on the risk associated with productive projects developed in the Latin American countries, namely, Argentine, Brazil, Chile, Colombia, Mexico and Peru, and the other emerging countries as well as on the risk associated with investments and financing.

Besides this introduction in Section 2, the methodological approach implemented in the research is presented. Section 3 presents the data or the sample used. The analysis of the results obtained in this research is reported in Section 4. Finally, Section 5 presents the conclusions and final comments of this work followed by the bibliographic references used.

\section{Methodological Approach}

The concept and the determination of the total risk and its portions systematic risk and idiosyncratic risk were established from the Single Index Model or the market model proposed by Sharpe (1963), which explains the risk asset portfolio returns through the returns of the market portfolio. In the scope of this work, the risk asset portfolio is characterized by the Brazilian stock market profitability index represented by the MSCI Brazil index while the emerging stock market profitability index was represented by the MSCI Emerging index, and the world stock market portfolio is characterized by the global equity market profitability index, represented by the MSCI ACWorld index. These indices are calculated by Morgan Stanley Capital International Financial Services Company and will be described in this work in the section dealing with the data used. The market model can be described as follows:

$$
R_{t}=\alpha+\beta R_{M t}+e_{t}
$$

where: $R_{t}=$ the return of MSCI-Brazil index or MSCI-Emerging index in period $t$; $R_{M t}=$ the return of ACWorld index in period $t$. Thus, the conditional average and conditional variance of the financial asset returns can be determined as follows:

$$
\begin{array}{clrl}
\text { Mean: } & E\left(R_{t} \mid R_{M t}\right) & =\alpha+\beta R_{M t} \\
\text { Variance: } & V\left(R_{t} \mid R_{M t}\right)=\beta^{2} V\left(R_{M t}\right)+V\left(e_{t}\right)
\end{array}
$$

The estimation of the beta coefficient, the primary indicator of market risk, takes place through linear regression models. For example in the works elaborated by Scholes and Williams (1993) using corrections from a classic univariate model and by Salles (2006) using a multivariate Bayesian model. The estimation of the idiosyncratic risk time series can be done through volatility models such as the ARCH family models, in particular, the GARCH model proposed by Bollerslev (1986). The GARCH model seeks to capture a standard behavior in financial asset return time series in which high values are also followed by high values in the following periods not necessarily in the 
same direction, following a predictable process. Therefore, a market model that allows obtaining estimates of the two components of the total risk can be built. Additionally, to the GARCH model, some of the primary models of the ARCH family were tested, such as ARCH, IGARCH, EGARCH, and TGARCH, as described in Enders (2010). Using the model selection criterion suggested by Akaike, the AIC which can be seen in detail in Gujarati and Porter (2011) or Wooldridge (2012), the market model to estimate the idiosyncratic risk was selected. With the alpha and betas parameters greater than zero, the volatility models estimated in this work assume their general form performed by the expressions described below: the ARCH (q) model represented by the expression (4); the GARCH (p, q) model represented by expression (5); the IGARCH (p, q) model represented by expression (6); the EGARCH (p, q, r) model represented by the expression (7); and TGARCH (p, q, r) model represented by the expression (8).

$$
\begin{gathered}
\sigma_{t}^{2}=\alpha_{0}+\sum_{j=1}^{q} \alpha_{j} e_{t-j}^{2} \\
\sigma_{t}^{2}=\alpha_{0}+\sum_{i=1}^{q} \alpha_{i} e_{t-i}^{2}+\sum_{j=1}^{p} \beta_{j} \sigma_{t-j}^{2} \\
\sigma_{t}^{2}=\sum_{i=1}^{q} \alpha_{i} e_{t-i}^{2}+\sum_{j=1}^{p} \beta_{j} \sigma_{t-j}^{2} \\
\ln \sigma_{t}^{2}=\alpha_{0}+\sum_{j=1}^{p} \beta_{j} \ln \sigma_{t-j}^{2}+\sum_{i=1}^{q} \alpha_{i}\left|\frac{e_{t-i}}{\sigma_{t-i}}-E\left(\frac{e_{t-i}}{\sigma_{t-i}}\right)\right|+\sum_{k=1}^{r} \gamma_{k} \frac{e_{t-i}}{\sigma_{t-i}} \\
\sigma_{t}^{2}=\alpha_{0}+\sum_{i=1}^{q} \alpha_{i} e_{t-i}^{2}+\sum_{j=1}^{p} \beta_{j} \sigma_{t-j}^{2}+\sum_{k=1}^{r} \gamma_{k} d_{\left(e_{t-k} \leq 0\right)}\left|e_{t-k}\right|^{2}
\end{gathered}
$$

Thus, the model used in this work to estimate idiosyncratic risk was a heteroscedastic linear regression model, where the stochastic terms are distributed according to a Student's t distribution and the variance given by a GARCH $(1,1)$ model which can be described as follows:

$$
\begin{gathered}
R_{t}=\alpha+\beta R_{M t}+e_{t}, e_{t} \sim \operatorname{Student}\left(0 ; \sigma_{t}^{2} ; v\right) \\
\sigma_{t}^{2}=\alpha_{0}+\alpha e_{t-1}^{2}+\beta \sigma_{t-1}^{2}
\end{gathered}
$$

\section{Sample - Data Used}

The primary data referring to the stock market indices that form the sample used in this work were collected on the Investing.com website. These indices are calculated and released by the financial services company Morgan Stanley Capital International (MSCI). These indicators were: the profitability index of the Argentine stock market - MSCI Argentina; the profitability index of the Brazilian stock market - MSCI Brazil; the profitability index of the Chilean stock market - MSCI Chile; the profitability index of the Colombian stock market - MSCI Colombia; the profitability index of the Mexican stock market - MSCI Mexico; the profitability index of the Peruvian stock market - MSCI Peru; the profitability index of the stock market of emerging countries - MSCI Emerging Markets; and the 
worldwide stock market profitability index - MSCI All-Country World Equity - or simply the MSCI ACWI Index. The Argentine stock market index covers $85 \%$ of the Argentine equity universe and includes the information technology (77.42\%), energy (13.32\%), and communication services (9.26\%) economic sectors. The Brazilian stock market index is made up of 56 shares and represents $85 \%$ of the equities traded in this country and includes the main sectors of the Brazilian economy. The Chilean stock market index brings together shares that represent the top ten firms operating in the Chilean economy covering most of the stock market and the most representative sectors of the Chilean economy such as utilities, financial, material, energy, and consumer. The Colombian stock market index concentrates on five firms covering the main sectors of the economy, namely: financial (55.45\%), energy (24.36\%), and utilities (20.19\%). The Mexican capital market indicator includes the main firms that operate in the economy distributed in the seven primary economic sectors in Mexico. The Peruvian index is concentrated in three firms that operate in the two dominant sectors of the economy: financial and material. All of these equity market indices that represent the economic activity behavior of the selected Latin American national economies are representative of their respective capital markets in the view of investors and asset managers operating in the international market. Further details about the MSCI Index mentioned here can be verified at https://www.msci.com.

For comparison of the Latin American markets idiosyncratic risk, the emerging markets index was used. This emerging markets index is composed of equities traded in China (33.00\%), South Korea (13.02\%), Taiwan (11.35\%), India (9.16\%), Brazil (7.73\%), South Africa (5.89\%), Russia (3.77\%), Mexico (2.55\%), Thailand (2.34\%) and others (11.59\%). Further details concerning the composition of the emerging countries stock markets indicator are at https://www.msci.com/. For market portfolio proxy, the global stock market index used is composed of equities from 11 sectors of the economy traded on the markets: 2 countries from developed countries in the Americas, 16 countries from Europe and the Middle East, and 5 countries from the Pacific; 6 countries from emerging countries in the Americas and 11 emerging countries from Africa, Europe, and the Middle East and 9 emerging countries from Asia. Further details about the description of this index can be seen at https://www.msci.com/acwi. All information collected was daily data in US\$, covering the period from June 30, 2017, to July 1, 2020.

Tables 1, 2, and 3 present the time series statistical summary used to obtain the research results, that is, an estimate of the idiosyncratic risk time series using the market model.

Regarding the equity market index time series of the Latin American countries, it can observe Table 1 and Table 2. From Table 1, it can be inferred from the location measures, that the mean and median are close for almost all the equity indices time series of Latin American economies. It can be noted that the median is less than the mean, which shows the existence of a positive asymmetry in the stock index quotes time series of the Argentine economy. In other selected Latin American economies, the opposite is observed. As for volatility, the equity indices time series of the Brazilian, Colombian and Mexican markets are similar while the Peruvian market is less volatile and the Argentine market stands out as the most volatile followed by the Chilean market. The asymmetry and kurtosis coefficients shown in Table 1 indicate that all Latin American equity index markets differ from a normal probability distribution, confirmed by the Jarque-Bera normality hypothesis test. The 
stationarity hypothesis tests of the stock index daily quote time series which represent the Latin American economies do not allow the stationarity hypothesis acceptance. For the Chilean and Mexican markets, however, the stationarity hypothesis cannot be rejected at the $10 \%$ significance level, which does not happen when the ADF test alternative without the constant and trend component was used. Therefore, the stationary hypothesis cannot be accepted for these time series.

Table 1. Statistical Summary of Latin American Market Index

\begin{tabular}{|l|c|c|c|c|c|c|}
\hline Statistics & $\begin{array}{c}\text { MSCI } \\
\text { Argentina } \\
\text { Index }\end{array}$ & $\begin{array}{c}\text { MSCI } \\
\text { Brazil } \\
\text { Index }\end{array}$ & $\begin{array}{c}\text { MSCI } \\
\text { Chile } \\
\text { Index }\end{array}$ & $\begin{array}{c}\text { MSCI } \\
\text { Colombia } \\
\text { Index }\end{array}$ & $\begin{array}{c}\text { MSCI } \\
\text { Mexico } \\
\text { Index }\end{array}$ & $\begin{array}{c}\text { MSCI } \\
\text { Peru } \\
\text { Index }\end{array}$ \\
\hline Mean & 2478.098 & 1974.890 & 1608.347 & 617.071 & 4857.366 & 1627.171 \\
\hline Median & 2188.845 & 2051.725 & 1676.490 & 637.950 & 4834.230 & 1662.680 \\
\hline Maximum & 4529.490 & 2428.710 & 2182.260 & 757.910 & 6145.470 & 1917.270 \\
\hline Minimum & 827.100 & 1036.300 & 697.860 & 262.550 & 2732.690 & 938.520 \\
\hline Std Deviation & 1042.389 & 299.284 & 340.940 & 97.507 & 742.128 & 204.447 \\
\hline Skewness & 0.451 & -1.226 & -0.557 & $-1,862$ & $-0,722$ & -1.564 \\
\hline Kurtosis & 1.916 & 3.999 & 2.593 & 5.917 & 3.426 & 5.013 \\
\hline Jarque-Bera & 64.922 & 229.100 & 45.835 & 729.985 & 74.020 & 451.273 \\
\hline (p value) & 0.000 & 0.000 & 0.000 & 0.000 & 0.000 & 0.000 \\
\hline ADF test & -2.100 & -2.586 & -3.409 & -2.120 & -3.189 & -2.093 \\
\hline (p value) & $(0.544)$ & $(0.287)$ & $(0.051)$ & $(0.533)$ & $0.087)$ & $(0.548)$ \\
\hline
\end{tabular}

Source: Author estimation with EViews from MSCI data.

Table 2 presents a statistical summary of the logarithmic variations or returns of the stock indices reported in Table 1. These variations were calculated as the logarithm of the quotient of the daily quote over the previous daily quote. Thus, from the quotation returns of the Latin American equity markets profitability indices, it can be observed for all selected markets that the return averages indicate the expectations of economic agents for future economic behavior were not optimistic as well as the investments in shares traded in these markets indicate losses in the period studied. Regarding the variability of high returns as expected, it can be inferred that the most volatile market among the studied markets is the Mexican, followed by the Chilean and the Argentine. On the other hand, among the equity markets that provided greater precision in the expectations of economic agents, that is, those that presented less volatility, there is the Brazilian followed by the Peruvian and the Colombian markets. Observing the asymmetry coefficients, it can be noted that all are negative and distant from a normal probability distribution coefficient. It must be highlighted that the kurtosis coefficients shown in Table 2 are very high, in particular, the returns kurtosis coefficients in the Argentine and the Colombian markets. Thus, the measures mentioned here show that the returns time series do not allow the normality hypothesis to be accepted which is confirmed with the Jarque-Bera normality test as can be seen in Table 2 . Thus, the adjustment to the data used in this work must be done with an alternative probability distribution to the normal probability distribution. And the Student's t probability distribution is the one that demonstrates to be the most adequate to fit the financial assets data. The information listed in Table 2 indicates that the stationarity hypothesis cannot be rejected for any time series returns for Latin American equity markets indexes. This was the expected result since the return can be seen as a first difference that, 
in general, makes the series of financial assets stationary. It should be noted that the results show the instability of the Argentine economy and, to a lesser extent, the Chilean economy in the period studied.

Table 2. Statistical Summary of Latin American Market Returns

\begin{tabular}{|l|c|c|c|c|c|c|}
\hline \multicolumn{1}{|c|}{ Statistics } & $\begin{array}{c}\text { MSCI } \\
\text { Argentina } \\
\text { Index } \\
\text { Return }\end{array}$ & $\begin{array}{c}\text { MSCI } \\
\text { Brazil } \\
\text { Index } \\
\text { Return }\end{array}$ & $\begin{array}{c}\text { MSCI } \\
\text { Chile } \\
\text { Index } \\
\text { Return }\end{array}$ & $\begin{array}{c}\text { MSCI } \\
\text { Colombia } \\
\text { Index } \\
\text { Return }\end{array}$ & $\begin{array}{c}\text { MSCI } \\
\text { Mexico } \\
\text { Index } \\
\text { Return }\end{array}$ & $\begin{array}{c}\text { MSCI } \\
\text { Peru } \\
\text { Index } \\
\text { Return }\end{array}$ \\
\hline Mean & -0.0011 & -0.0002 & -0.0006 & $-0,0006$ & -0.0007 & -0.0003 \\
\hline Median & 0.0000 & 0.0006 & -0.0006 & 0.0000 & -0.0003 & 0.0001 \\
\hline Maximum & 0.1187 & 0.1516 & 0.1045 & 0.1594 & 0.0686 & 0.1018 \\
\hline Minimum & -0.5113 & -0.1943 & -0.1674 & $-0,2190$ & -0.1118 & -0.1356 \\
\hline Std Deviation & 0.0329 & 0.0238 & 0.0179 & 0.0217 & 0.0168 & 0.0166 \\
\hline Skewness & -4.9629 & -1.4790 & $-1,3881$ & -2.3073 & -1.0217 & $-1,3642$ \\
\hline Kurtosis & 77.1900 & 19.2500 & 21.9667 & 38.4952 & 10.1427 & 16.4273 \\
\hline Jarque-Bera & 183020.9 & 8911.8340 & 12003.18 & 41852,72 & 1802.983 & 6132.670 \\
\hline (p value) & 0.0000 & 0.0000 & 0.0000 & 0.0000 & 0.0000 & 0.0000 \\
\hline ADF test & -7.781 & -6.266 & -7.201 & -7.894 & -7.404 & -9.192 \\
\hline (p value) & $(0.000)$ & $0.000)$ & $(0.000)$ & $0.000)$ & $0.000)$ & $0.000)$ \\
\hline
\end{tabular}

Source: Author estimation with EViews from MSCI data.

Table 3 refers to MSCI ACWorld Index and MSCI Emerging Index and it can be seen that the time series location measures are disparate and do not have symmetry. Concerning the volatility of the return time series, these are high, as expected from market price returns or variations. As for the asymmetry and kurtosis coefficients: it can be seen that all the asymmetry coefficients shown in Table 3 differ from the asymmetry coefficient of a normal probability distribution. The same happens regarding the kurtosis coefficients calculated for all time series used. The Jarque-Bera test confirms the inferences made from observing the asymmetry and kurtosis coefficients, that is, for every of the time series used the normality hypothesis cannot be accepted. Concerning the stationarity hypothesis of the time series summarized in Table 3, the stationarity possibility of the MSCI-ACWorld index quotes time series cannot be rejected according to the results of the ADF test. However, it should be noted that the extensions to the ADF test do not allow stationary hypothesis acceptance of the global equity index MSCI-ACWorld quotations. Regarding the MSCI-Emerging markets index, although stationarity is not rejected at the $8 \%$ level of significance for the ADF test alternatives, without the constant or the trend component, it points to an opposite decision. That is, the portfolio index that corresponds to the equities traded in emerging countries the stationarity hypothesis is not accepted. 
Table 3. Statistical Summary of Time Series - World and Emerging Index

\begin{tabular}{|l|c|c|c|c|}
\hline \multicolumn{1}{|c|}{ Statistics } & $\begin{array}{c}\text { MSCI } \\
\text { ACWorld } \\
\text { Index }\end{array}$ & $\begin{array}{c}\text { MSCI } \\
\text { Emerging } \\
\text { Index }\end{array}$ & $\begin{array}{c}\text { MSCI } \\
\text { ACWorld } \\
\text { Index Return }\end{array}$ & $\begin{array}{c}\text { MSCI } \\
\text { Emerging } \\
\text { Index Return }\end{array}$ \\
\hline Mean & 508.453 & 1055.617 & 0.0002 & -0.0001 \\
\hline Median & 510.795 & 1054.860 & 0.0007 & 0.0006 \\
\hline Maximum & 581.020 & 1273.070 & 0.0806 & 0.0557 \\
\hline Minimum & 384.040 & 758.200 & -0.1000 & -0.0694 \\
\hline Std Deviation & 29.004 & 83.336 & 0.0111 & 0.0107 \\
\hline Skewness & -0.254 & -0.257 & -1.7250 & -1.0731 \\
\hline Kurtosis & 4.357 & 3.467 & 26.5880 & 11.5687 \\
\hline Jarque-Bera & 68.547 & 15.740 & 18564.320 & 2548.9370 \\
\hline (p value) & 0.000 & 0.0004 & 0.0000 & 0.0000 \\
\hline ADF test & -3.428 & -3.2140 & -6.7032 & -9.5897 \\
\hline (p value) & $0.049)$ & $(0.0824)$ & $0.0000)$ & $0.0000)$ \\
\hline
\end{tabular}

Source: Author estimation with EViews from MSCI data.

\section{Analysis of Results Obtained}

In order to estimate the idiosyncratic risk, hereafter IDR, associated with the economic activities for each Latin American economies selected and the emerging countries equity markets, Single Index Models or market models were estimated according to the descriptions in Section 3. That is, in these market models the returns of the profitability index of each economy, given by the MSCI equity profitability index were used as the response variable for each selected country while the market portfolio provided by the MSCI-ACWorld (ACW) index was used as a regressor.

These market models were selected among the estimated models with all the significant parameters among the models estimated with different combinations, that is, varying: the estimation of the constant parameter in the average model; the probability distribution of stochastic terms, normal or Student's t; inclusion of dummy variables in the average and/or variance; and the volatility model. Additionally, as observed from the Pan American Health Organization (PAHO) information at https://www.paho.org/bra, these variable dummies consider the following dates: the d23j variable -- January 23rd, the day of the first lockdown in Wuhan in China; the d30j variable -- January 30th, the outbreak declaration date from the World Health Organization - WHO, that declares that the outbreak of the new coronavirus is a Public Health Emergency of International Importance (ESPII) and it is spread in 19 countries; and the $\mathrm{d} 11 \mathrm{~m}$ variable -- March 11th, when Covid-19 epidemic was characterized as a pandemic by the World Health Organization - WHO. This way, the binary or dummy variable can be described in the following form: $\mathrm{d} 23 \mathrm{j}$ ( 0 : before 23rd January, 1: after this date); $\mathrm{d} 30 \mathrm{j}$ ( 0 : before 30th January, 1: after this date); and d30m (0: before 30th March, 1: after this date). The variable dummies were added to the market model in the mean and/or variance.

Regarding the Argentine market idiosyncratic risk, the IDR time series was estimated using the market model without intercept and a TGARCH model $(1,1,1)$ for the variance adding the dummy variable $\mathrm{d} 23 \mathrm{j}$ as a regressor. The Argentine market model was selected among 16 models estimated 
in different forms and it is described in expressions (11) and (12), with the estimates and the necessary metrics to observe the performance of the estimates obtained listed in (13).

With regards to the idiosyncratic risk of the Brazilian market, the time series was estimated using the market model for mean and an EGARCH model (p, q, r) for variance. The market model selected for the mean was used without intercept. Thus, the selected model was similar to that described by the expressions in (9), without the $\alpha$ parameter, with the EGARCH model $(1,1,1)$ replacing the expression (10) since this model was selected using the criterion AIC. This model was selected among the 18 models with all the significant parameters among the 175 models estimated with different combinations. Therefore, the IDR-Brazil was obtained by estimating the market model without intercept term in the average, where the stochastic terms adjusted to a Student's $t$ distribution with approximately 6 degrees of freedom and an EGARCH $(1,1,1)$ model for the variance. The selected model is described in expressions (14) and (15), with the estimates and the necessary metrics to observe the performance of the estimates obtained listed in (16).

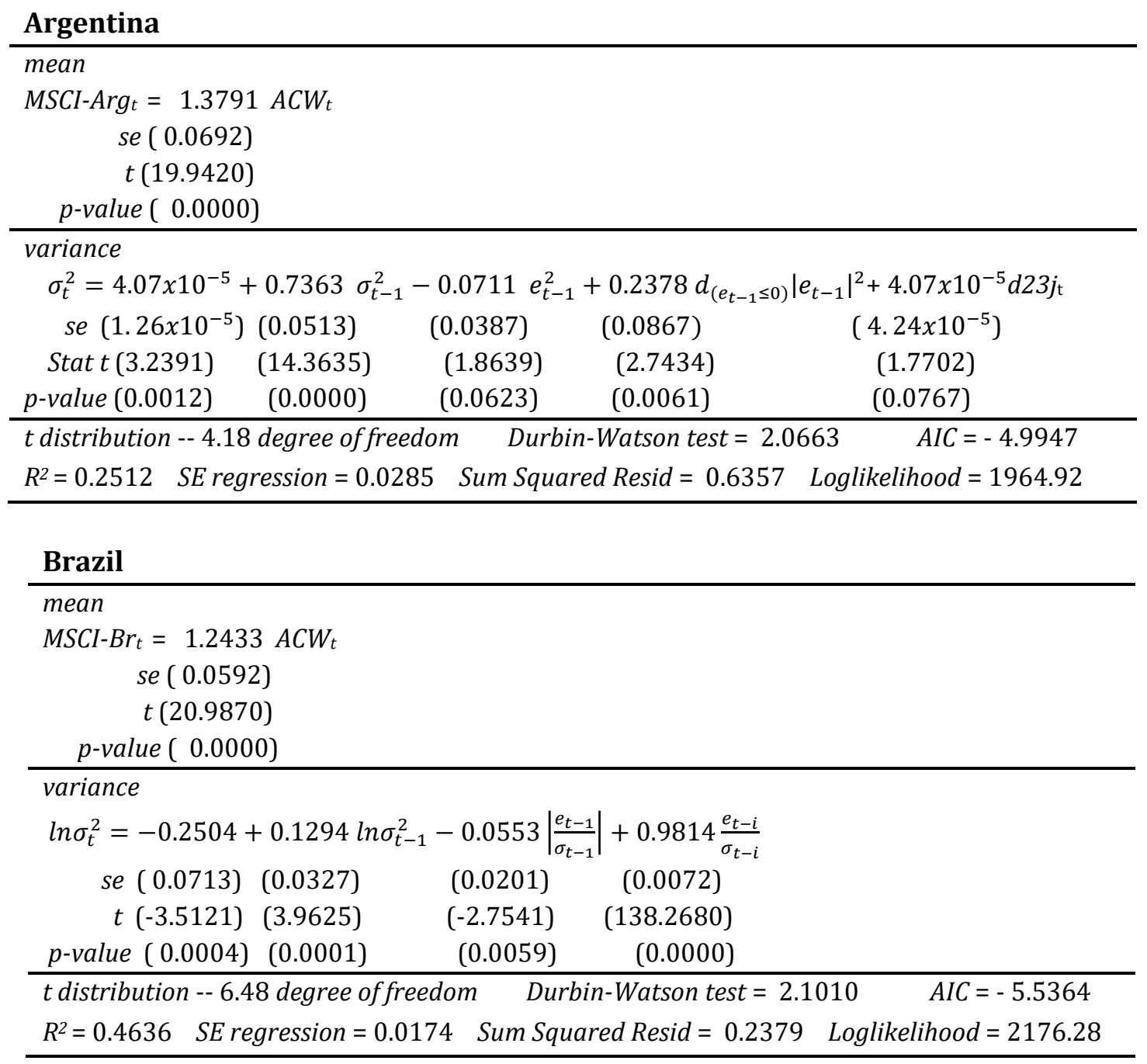


Regarding the IDR time series estimated for the Chilean economy, the market model selected among 26 estimated models with the same average show in the expression (9) was used. To the variance, a GARCH $(1,1)$ model with the dummy variable $\mathrm{d} 23 \mathrm{j}$ added as a regressor and the stochastic terms adjusted to a Student's t distribution with close to 5 degrees of freedom were used. These results are described in expressions (17) and (18), and the metrics performance of estimates obtained are listed in (19).

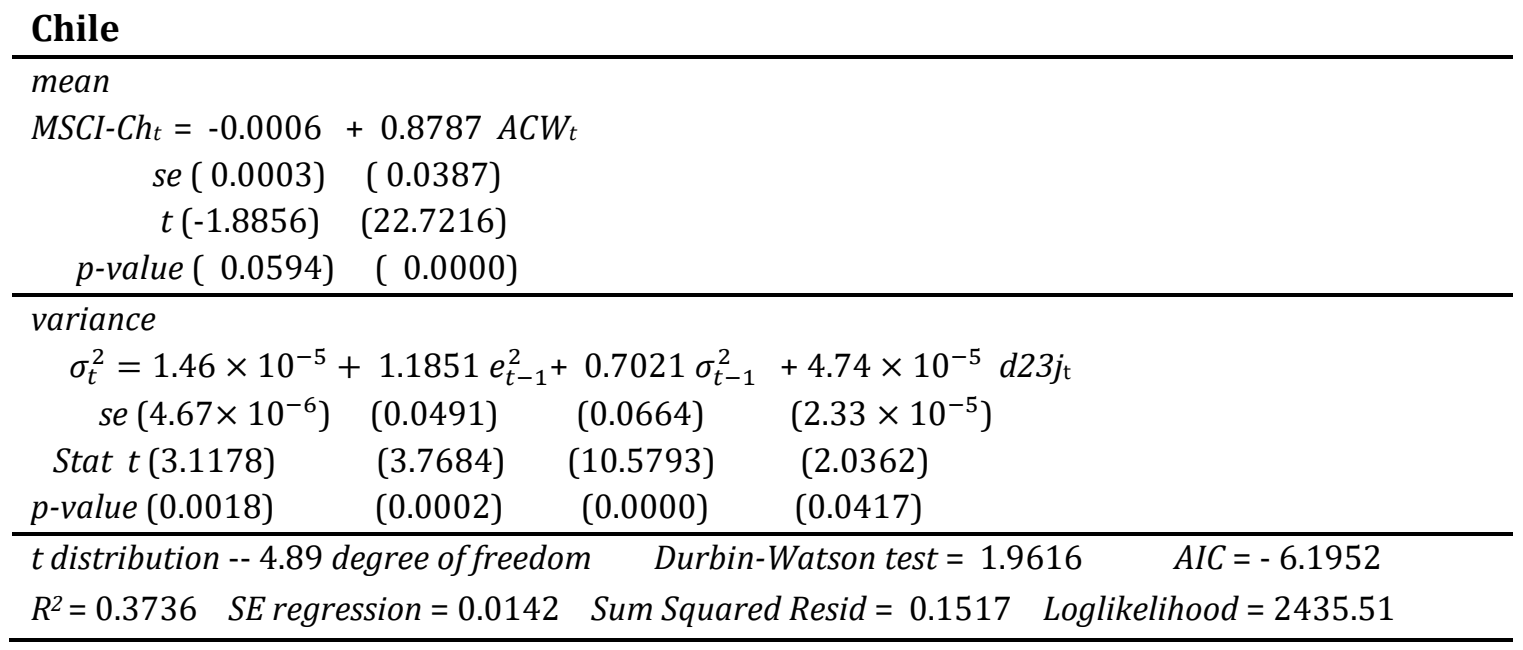

\section{Colombia}

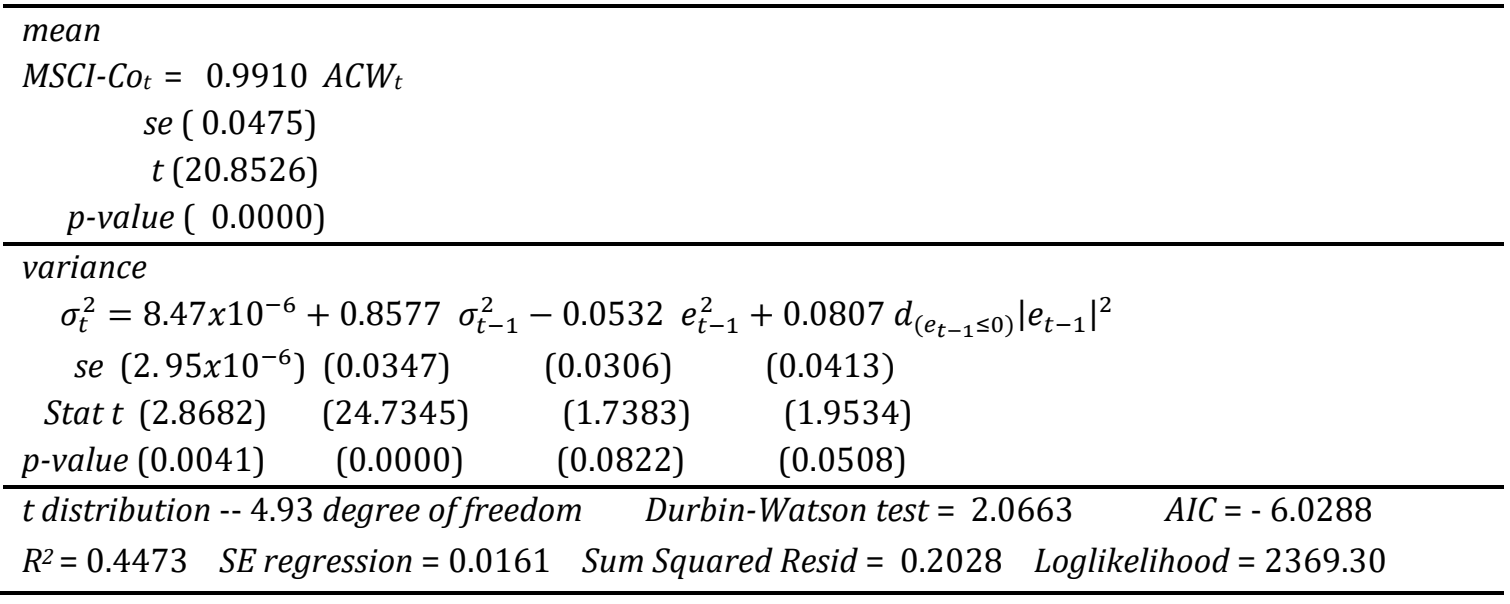

The market model for the Colombian economy IDR was estimated with the mean shown in the expression (9) without intercept and the TGARCH $(1,1,1)$ for variance and the stochastic terms adjusted to a Student's t distribution with close to 5 degrees of freedom. The results are represented by the expression (20) and (21) respectively, for the mean and variance and the necessary metrics to observe the performance of the estimates obtained listed in (22).

With regards to the Mexican market IDR, the time series was estimated using the market model in the same form of the expression (9) and a GARCH model $(1,1)$ for the variance adding the dummy variable $\mathrm{d} 23 \mathrm{j}$ as a regressor. The Mexican market model was selected among 21 models 
estimated in different forms and it is described in expressions (23) and (24), with the necessary metrics to observe the performance of the estimates obtained which are listed in (25).

Looking at the Peruvian economy IDR, the market model selected among 15 estimated models has the average with the same form of the formula shown in (9) without the intercept and with the dummy $\mathrm{d} 23 \mathrm{j}$ addition as a regressor. For the variance, a GARCH $(1,1)$ model with the dummy $\mathrm{d} 23 \mathrm{j}$ addition as a regressor was used. The Peruvian IDR results, estimated with the stochastic terms adjusted to a Student's $t$ distribution with close to 5 degrees of freedom, are described in the expressions (26) and (27), and the metrics performance of estimates obtained are listed in (28).

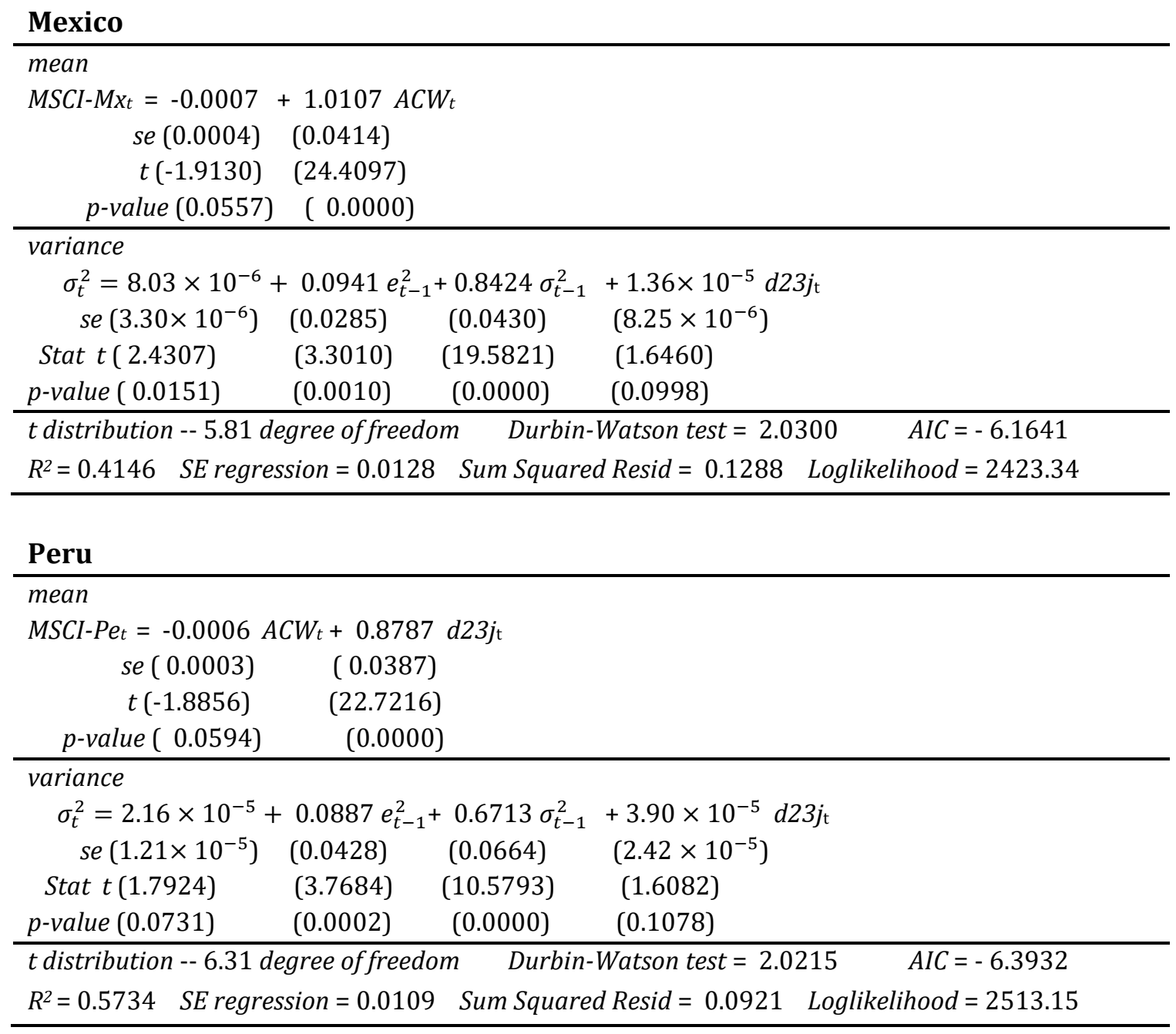

It must be highlighted that for the Brazilian and the emerging markets estimate the three dummy variables were used. On the other hand, in other Latin American markets, the $d 23 \mathrm{j}$ variable is the only dummy variable used. Due to this, the number of estimated models differs among the countries selected for this work. The use of the dummy variable $\mathrm{d} 23 \mathrm{j}$ to the detriment of others was done based on the results obtained for the Brazilian market and the significant results of this binary variable presented by Akhtaruzzaman et al. (2020). 
The market model for emerging countries was estimated, to compare with the results obtained for the IDR Latin American countries time series. Thus, the same methodology was used to obtain the Latin American countries IDR using the MSCI-Emerging index (MSCI-Em), in that way obtaining estimates for IDR Emerging markets. From 18 estimated models, the model selected using the AIC criterion is described in expressions (29) and (30) respectively, for the mean and for the variance, given by a GARCH model, and the performance metrics are listed in (31).

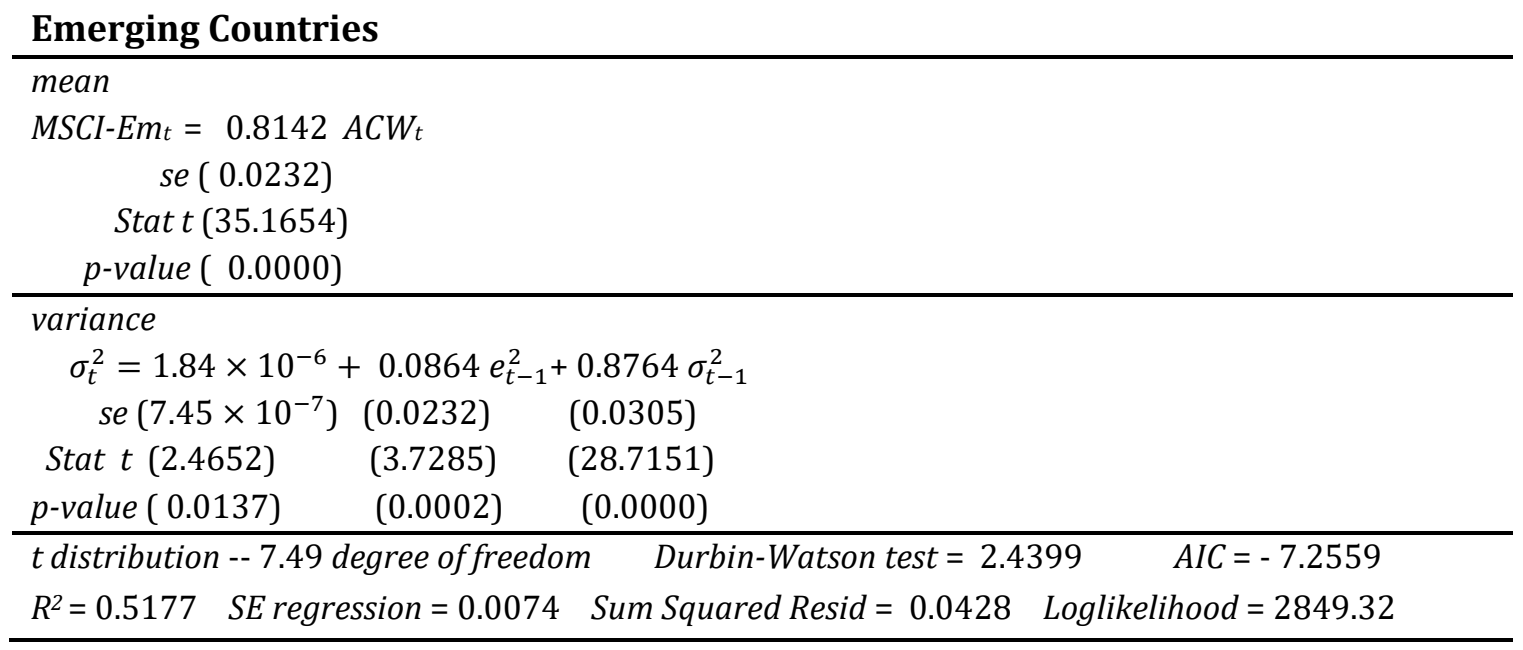

Table 4 presents a statistical summary of idiosyncratic risk estimated for a portfolio of emerging markets and the main Latin American markets. Table 4 shows that the location measures of the idiosyncratic risk time series estimated for the Argentine stock market differ significantly from the other idiosyncratic risk time series. It can be seen that the lowest average occurs in the time series that represents the idiosyncratic risk of the Peruvian economy followed by that of the Mexican, Chilean, Colombian and Brazilian economies. All the Latin American markets idiosyncratic risk time series show themselves to be superior to the same risk as in a portfolio of emerging countries given by the MSCI Emerging index. Regarding the volatility of the IDR time series, it should be noted that Chile, Colombia, and Mexico have similar behaviors and the Brazilian IDR has greater variability than these time series. When the entire period studied is observed, it must be highlighted that the Argentine idiosyncratic risk has a low variability regarding other markets. As for the asymmetry coefficient, all time series are positively asymmetric. The Argentine IDR shows the greatest asymmetry while the Brazilian IDR and the Peruvian come close to a normal probability distribution. It can be seen that all time series differ from that of a normal probability distribution, as can be inferred through the Jarque-Bera normality test. 
Table 4. Statistical Summary of Latin American Market IDR

\begin{tabular}{|l|c|c|c|c|c|c|c|}
\hline Statistics & $\begin{array}{c}\text { IDR } \\
\text { Argentine }\end{array}$ & $\begin{array}{c}\text { IDR } \\
\text { Brazil }\end{array}$ & $\begin{array}{c}\text { IDR } \\
\text { Chile }\end{array}$ & $\begin{array}{c}\text { IDR } \\
\text { Colombia }\end{array}$ & $\begin{array}{c}\text { IDR } \\
\text { Mexico }\end{array}$ & $\begin{array}{c}\text { IDR } \\
\text { Peru }\end{array}$ & $\begin{array}{c}\text { IDR } \\
\text { Emerging }\end{array}$ \\
\hline Mean & 0.0009 & 0.0003 & 0.0002 & 0.0002 & 0.0002 & 0.0001 & 0.0001 \\
\hline Median & 0.0004 & 0.0002 & 0.0001 & 0.0001 & 0.0001 & 0.0001 & 0.0000 \\
\hline Maximum & 0.0777 & 0.0019 & 0.0032 & 0.0039 & 0.0013 & 0.0007 & 0.0006 \\
\hline Minimum & 0.0002 & 0.0001 & 0.0001 & 0.0001 & 0.0002 & 0.0001 & 0.0000 \\
\hline Std Deviation & 0.0041 & 0.0003 & 0.0003 & 0.0005 & 0.0002 & 0.0001 & 0.0001 \\
\hline Skewness & 13.6305 & 2.7427 & 5.3012 & 5.5260 & 3.8269 & 3.0810 & 5.6568 \\
\hline Kurtosis & 213.9896 & 11.5619 & 39.2712 & 35.6803 & 20.9054 & 15.2636 & 40.5781 \\
\hline Jarque-Bera & 1478486 & 3377 & 46648 & 38878 & 12387 & 6153 & 50310 \\
\hline (p value) & 0.0000 & 0.0000 & 0.0000 & 0.0000 & 0.0000 & 0.0000 & 0.0000 \\
\hline Observations & 784 & 784 & 784 & 784 & 784 & 784 & 784 \\
\hline
\end{tabular}

Source: Author estimation with EViews from MSCI data.

Looking at the Argentine IDR in Figure 1, it can be observed that the Argentine economy differs from the behavior of the other selected Latin American economies. The Argentine idiosyncratic risk time series plot behavior shows that throughout the period under study the idiosyncratic risk remains at a much higher level than the idiosyncratic risk of emerging markets. It should be noted that in August and September 2018, abnormal behavior of the Argentine idiosyncratic risk happened. Thus, the two plots shown in Figure 1 seem to hide the idiosyncratic emerging markets time series given the magnitude of the Argentine idiosyncratic risk plot values, confirming the analysis made previously in Table 4 about the Argentine idiosyncratic risk disparity from the others.

Thus, the IDR-Brazil and the IDR-Emerging were obtained from the market model, for Brazil and the other emerging countries, respectively. The two plots in Figure 2 illustrates the IDR-Brazil and the IDR-Emerging time series behavior. Regarding the IDR-Brazil, the risk associated with investments and financing of economic activities in Brazil can be observed. In the period near the end of the first half of 2018, an increase with variations until the same period in 2019 can be observed, maintaining a lower level with peaks close to the beginning of September and December 2019. At the end of February 2020, the IDR-Brazil plot shows an atypical behavior reaching a peak, the highest level in the period studied, on March 17th, 2020 after March 11th, when the Covid-19 epidemic was characterized as a Pandemic by WHO. At the end of April 2020, the IDR-Brazil decreased and then grew until the end of this month. From Figure 2, it can be inferred that the IDR-Brazil is always above the idiosyncratic risk of the emerging countries portfolio group. Another relevant inference from the observation of IDR-Brazil plot behavior that can be done is at the end of the period studied on June 30th, 2020 when the lowest level of risk occurs in the period after the decree of the Covid-19 Pandemic by WHO, which corresponds to the highest idiosyncratic risk level of emerging countries on March 23rd, 2020. 
-- June 2017 - July 2020 --

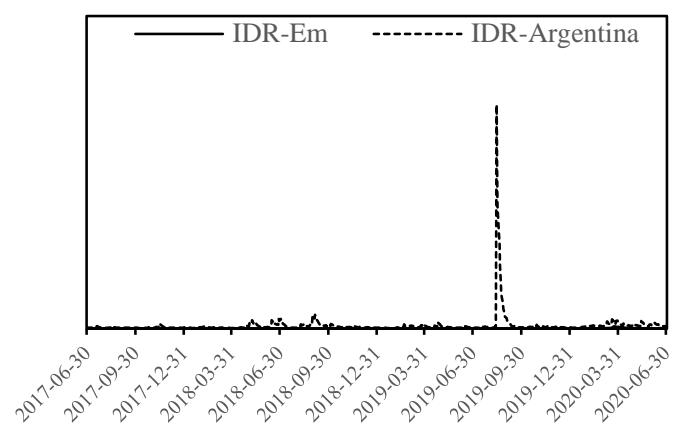

-- January 2020 - July 2020 --

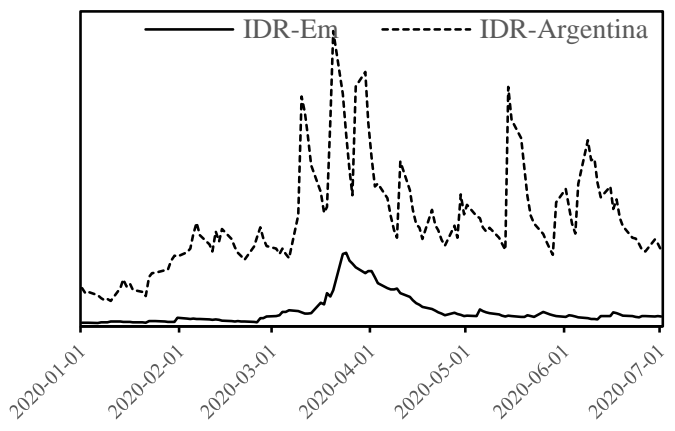

Figure 1. The Idiosyncratic Risk of the Argentine Market and the Emerging Markets Source: Author estimations using EViews and Excel from MSCI data.
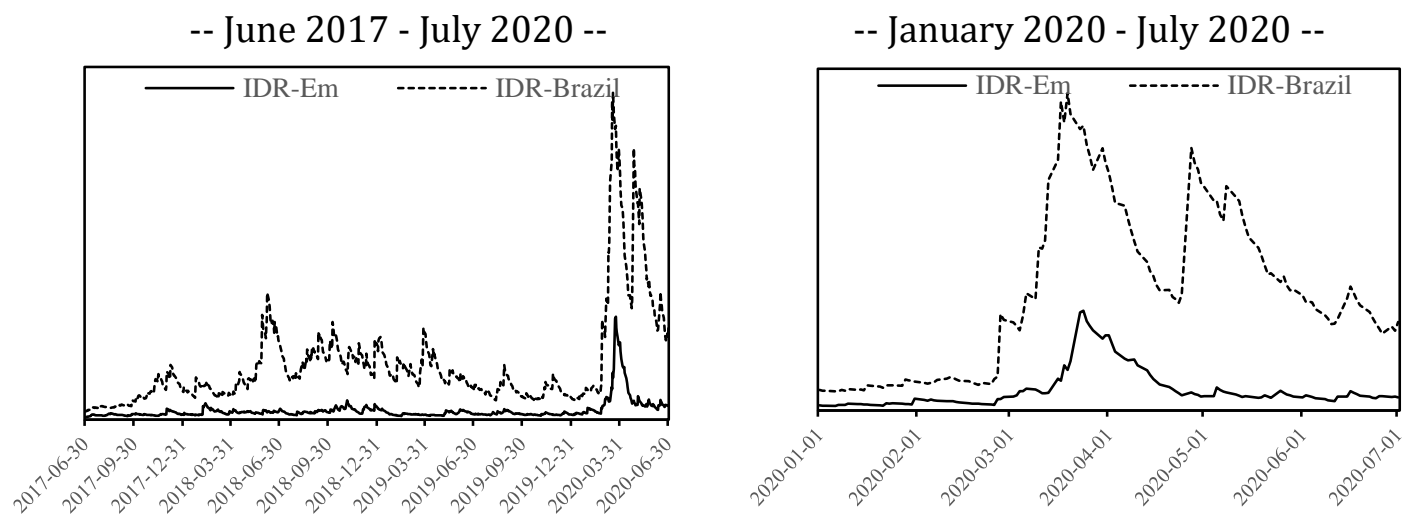

Figure 2. The Idiosyncratic Risk of the Brazilian Market and the Emerging Markets Source: Author estimations using EViews and Excel from MSCI data.

-- June 2017 - July 2020 --

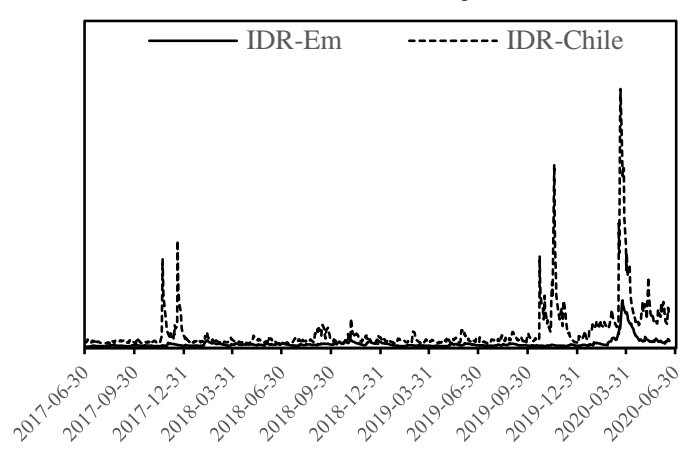

-- January 2020 - July 2020 --

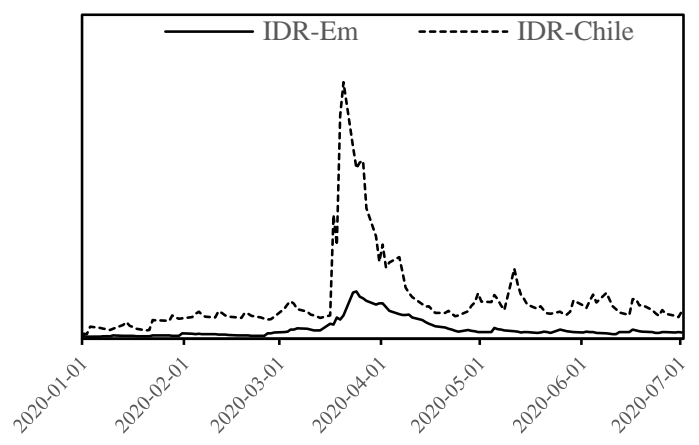

Figure 3. The Idiosyncratic Risk of the Chilean Market and the Emerging Markets Source: Author estimations using EViews and Excel from MSCI data. 

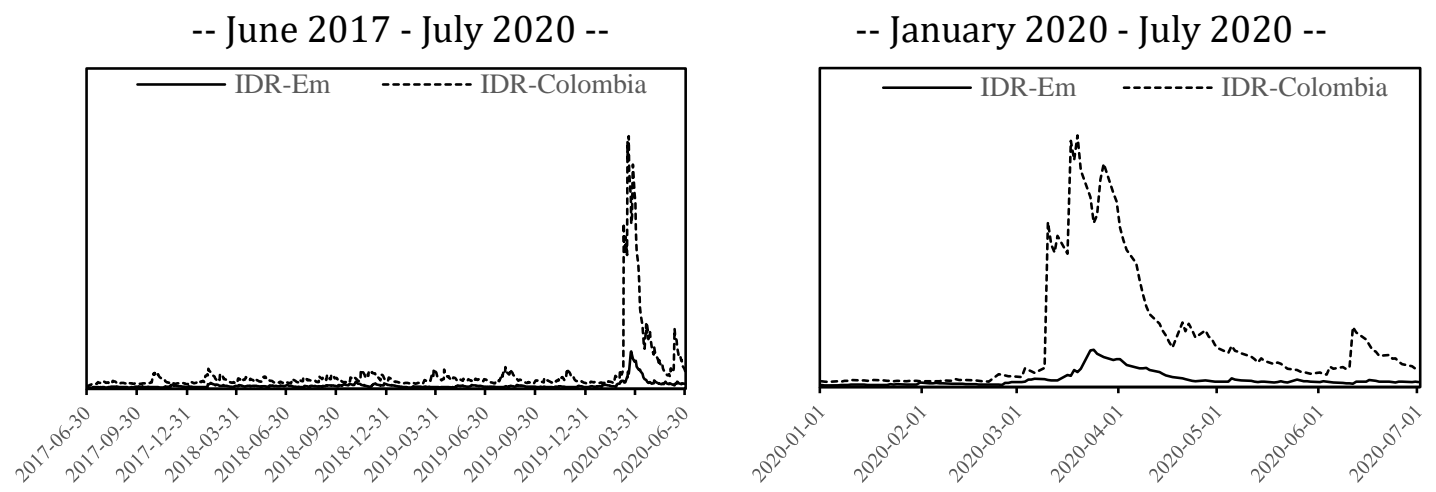

Figure 4. The Idiosyncratic Risk of the Colombian Market and the Emerging Markets Source: Author estimations using EViews and Excel from MSCI data.

Regarding Figure 3, it can be noted that at the end of 2017 period, more precisely in November and December, there were two abrupt increases in the Chilean IDR and in the period that follows, that is, after December 2017 the idiosyncratic risk remains with high variability and at a higher level than the emerging markets IDR until mid-October 2019 when the specific risk associated with economic activity in Chile increases sharply as it did at the end of 2017 which is repeated at a much higher level, returning to the previous levels of the end of December 2019. Before the impact caused by the Covid-19 Pandemic in emerging economies, given by the IDR-Em, the Chilean IDR experiences increases which initiate in March 2020 reaching the highest level in the period studied around March 18th, 2020. It shows that the effects of the Covid-19 Pandemic were more striking in the Chilean economy than in the emerging markets portfolio of the global economy. This is verified in the rest of the studied period, as shown in the IDR-Chile plot behavior in Figure 3.

Figure 4 shows that the time series of the estimated idiosyncratic risk for the Colombian market has similar behavior in most of the sample period used in this work, with variations and peaks within the same interval until the beginning of March 2020. However, as from this date, IDR-Colombia has shown extraordinary growth as it occurred in all the emerging economies studied in this work, but in a much higher proportion than occurred in idiosyncratic risk time series of other Latin American economies. The Colombian idiosyncratic risk reaches its maximum on March 17th, 2020, and returns to a much higher level than the idiosyncratic risk in emerging markets on May 29th, 2020, returning to another peak on June 11th, 2020. Thus, the Colombian idiosyncratic risk plot shows an evident impact of the Covid-19 pandemic on the specific risk associated with productive projects or the economic activity carried out in the Colombian economy. It should also be noted that throughout the study period, the Colombian idiosyncratic risk is always higher in level than emerging countries idiosyncratic risk. 
-- June 2017 - July 2020 --

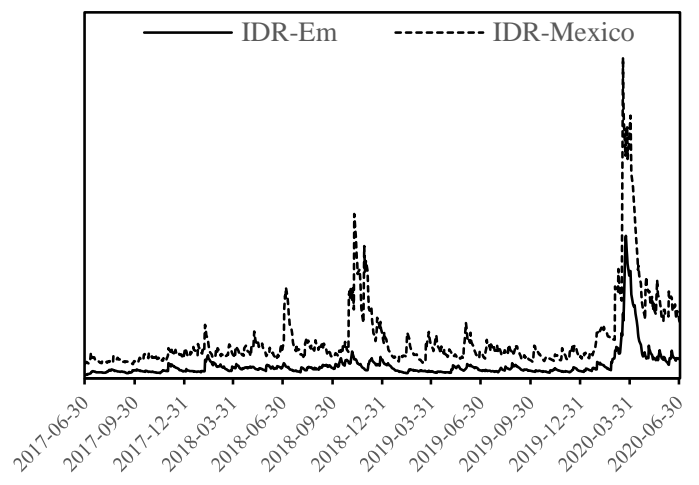

-- January 2020 - July 2020 --

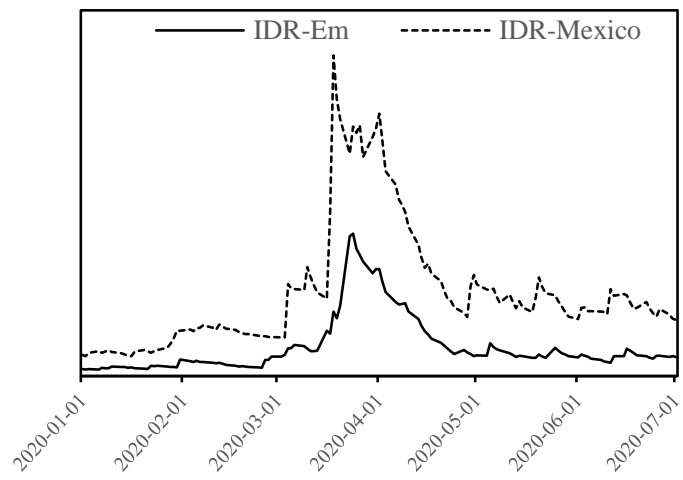

Figure 5. The Idiosyncratic Risk of the Mexican Market and the Emerging Markets Source: Author estimations using EViews and Excel from MSCI data.

-- June 2017 - July 2020 --

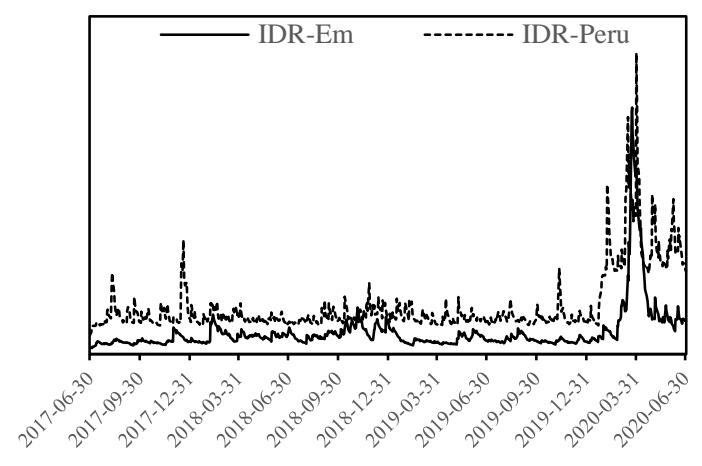

-- January 2020 - July 2020 --

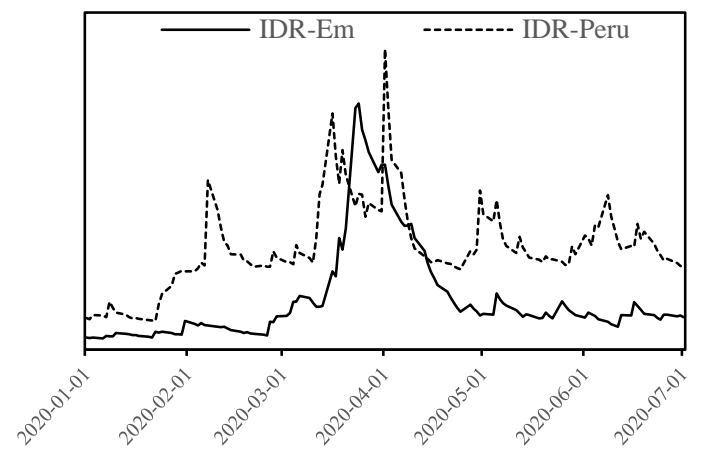

Figure 6. The Idiosyncratic Risk of the Peruvian Market and the Emerging Markets Source: Author estimations using EViews and Excel from MSCI data.

Figure 5 shows that the behavior of the Mexican idiosyncratic risk plot demonstrates that economic activity in Mexico had different moments throughout the studied period. Around February 7th, 2018, and between June and August 2018, the idiosyncratic risk estimates reached levels well above those observed in the period studied until the end of January 2020, when the emerging markets and, mainly, the Mexican market indicate an evident impact of the crisis generated by the Covid-19 pandemic. Thus, as from the end of January, the Mexican IDR indicates a growth that reaches the highest levels at the end of March 2020, decreasing at the end of April. It should be noted that the effects of the Covid-19 pandemic crisis on the Mexican IDR are more intense than those of the emerging IDR. It can be seen that from the end of March 2020, the period of greatest influence of the Covid-19 pandemic on economic activities, the idiosyncratic risk indicators of Mexico and the emerging markets, respectively, differ and distance themselves more than at other times that characterize the analyzed period.

Regarding the estimate of the Peruvian economy idiosyncratic risk time series, the plot presented, together with the emerging markets idiosyncratic risk, in Figure 6 shows that the specific risk associated with the financing and investment of economic activities in Peru has an anomalous behavior in the period in around August 10th, 2017 returning to its typical behavior of high 
variability in a higher level above the emerging markets portfolio idiosyncratic risk. Around December 19th, 2017 another abnormal rise in the Peruvian idiosyncratic risk takes place. Around November 16th, 2018, it can be seen from the plots in Figure 6 that the emerging markets idiosyncratic risk experiences greater growth than it is not accompanied by the Peruvian idiosyncratic risk. On November 11th, 2019 a peak in the time series of the Peruvian equity market idiosyncratic risk can be observed at the same level as observed in August 2017 or at the beginning of the period studied. As of the end of January 2020, the Peruvian idiosyncratic risk experiences a significant increase greater than that of emerging markets idiosyncratic risk. And from this moment on, there was a marked increase in the idiosyncratic risk practiced in the Peruvian market, when the effects of the crisis caused by the Covid-19 pandemic began to be absorbed by economic activities, particularly, by the specific risk associated. It is important to highlight that among the Latin American markets selected for this work the Peruvian idiosyncratic risk growth given by the impact of the Covid-19 pandemic is the closest to the emerging markets idiosyncratic risk growth in the period close to the pandemic decree by the World Health Organization (WHO).

All the estimated idiosyncratic risk time series presented here show through extraordinary behavior evidence of an expressive initial impact of the Covid-19 pandemic on the idiosyncratic or specific risk associated with the investment and financing of economic activities in the Latin American markets.

In the analysis of the results obtained through the plots, there was no concern to associate the events observed in these graphs with the events that occurred in the economy of each country on the same dates. This work had as the main objective to verify the impact of the Covid-19 pandemic on the idiosyncratic risk in Latin American economies selected for this work. Hence, another analysis that associate relevant economic event with the idiosyncratic risk time series could be the object of study for future work.

\section{Conclusions and Final Remarks}

This work aimed to carry out initial studies on the impacts of the Covid-19 pandemic on national economies through idiosyncratic risk, associated with economic activity in Latin American and other emerging economies. The primary objective of this paper was to verify this impact on Latin American economic activity. This work used a methodological approach based on the portfolio theory to obtain estimates of the idiosyncratic risk associated with the financing and investment of economic activity in Latin America, or the productive projects implemented in the Latin American economies. One of the two installments of the total risk of an asset portfolio, or an economy, is the idiosyncratic risk, allowing to observe the part of the total risk that refers only to the asset portfolio or to a particular national economy. Thus, once the idiosyncratic risk can be estimated through the market model, heteroscedastic market models were estimated for a portfolio of assets in the Latin American economies and a portfolio of assets traded in emerging countries. In addition to heteroscedastic conditional models, Student's t distribution was used in these models as an alternative to the normal distribution for the stochastic terms. 
The idiosyncratic risk time series estimated allowed observing the impact or influence of the Covid-19 pandemic on the risk of the Latin American economic activities and the emerging economies over the studied period. It should be emphasized that the allocation of resources in productive projects, or in national economies, occurs by observing the trade-off risk and return. This way, resource managers available for applications in the international market seek to invest in projects and in national economies that can offer returns compatible with the level of risk externalized in the international market. The level of specific or idiosyncratic risk associated with economic activity in Latin America demonstrated itself well above the risk of other emerging countries, in the entire period of the sample studied, which was accentuated by the Covid-19 pandemic. The inability of emerging countries to generate the necessary savings to finance their development imposes the need for emerging or developing countries to attract resources to finance their development projects. The results presented here indicate that Latin American countries provide an indicator of capital attractiveness at a level below those of the emerging countries in the global economy as can be observed in these economies' idiosyncratic risk. Moreover, the specific risk estimated for Latin American economies indicates that the attractiveness of the necessary resources for investment and financing of development projects of these countries in recent periods were at a higher level than the average for emerging economies in the world. The impact of the Covid-19 pandemic has increased this difference. It must be emphasized that Latin American economies are more susceptible to the effects of crises that affect the world economy, such as the crisis caused by the Covid-19 pandemic.

As a follow up of this research the use of volatility multivariate models as the multivariate GARCH model to estimate the idiosyncratic risk of each economy in the Latin American and their associations would be an appealing methodological approach alternative. Other groups of economies should also be considered. Thus, future works can be performed with other samples and methodologies that will provide more accurate results to allow for further subsidies that will contribute to minimizing the Covid-19 pandemic effects in the economic activities, particularly the financing and investment of production.

\section{References}

[1] Akhtaruzzaman, M., Boubaker, S., Chiah, M., Zhong, A. (2020). COVID-19 and oil price risk exposure. Finance Research Letters, Available online 5 December 2020. https://doi.org/10.1016/j.frl.2020

[2] Alam, M., Alam, S., Chavali, K. (2020). Stock Market response during COVID-19 Lockdown Period in India: An Event Study. Journal of Asian Finance, Economics and Business, 7 (7), pp. 131-137. https://doi.org/10.13106/jafeb.2020.vol7.no7.131

[3] Anderson, R. M., Heesterbeek, H., Klinkenberg, D., Déirdre Hollingsworth, T. (2020). How will countrybased mitigation measures influence the course of the COVID-19 epidemic? The Lancet, v. 395, n. 10228, p. 931-934. https://doi.org/10.1016/s0140-6736(20)30567-5

[4] Angelidis, T., Tessaromatis, N. (2008). Idiosyncratic Volatility and Equity Returns: UK Evidence. International Review of Financial Analysis, 17, pp. 539-556. https://doi.org/10.1016/j.irfa.2006.10.006

[5] Atkeson, A. (2020). What Will Be the Economic Impact of Covid-19 in the US? Rough Estimates of Disease Scenarios. NBER Working Paper Series, Available at http://www.nber.org/papers/w26867. https://doi.org/10.3386/w26867 
[6] Barro, R., Ursua, J., Weng, J. (2020). The Coronavirus and the Great Influenza Epidemic - Lessons from the "Spanish Flu" for the Coronavirus's Potential Effects on Mortality and Economic Activity. CESifo Working Paper Series No. 8166. Available at https://ssrn.com/abstract=3556305. https://doi.org/10.3386/w26866

[7] Blitz, D., Hanauer, M. X., Vidojevic, M. (2020). The Idiosyncratic Momentum Anomaly. International Review of Economics \& Finance, 69, 932-957. https://doi.org/10.1016/j.iref.2020.05.008

[8] Bollerslev, T. (1986). Generalized Autoregressive Conditional Heteroskedasticity. Journal of Econometrics, 31, pp. 307-327. https://doi.org/10.1016/0304-4076(86)90063-1

[9] Campbell, J., Lettau, M., Malkiel, B., Xu, Y. (2008). Have Individual Stocks Become More Volatile? An Empirical Exploration of Idiosyncratic Risk, The Journal of Finance, 56, pp. 1-43. https://doi.org/10.1111/0022-1082.00318

[10] Chang, R., Ko, K., Nakano, S., Rhee, S. (2018). Residual momentum in Japan. Journal Empirical Finance, 45, pp. 283-299. https://doi.org/10.1016/j.jempfin.2017.11.005

[11] Enders, W. (2010). Applied Econometric Time Series. $3^{\text {th }}$ Ed, John Wiley \& Sons, New York.

[12] Engle, R. (1982). Autoregressive Conditional Heteroscedasticity with Estimates of the Variance of United Kingdom Inflation. Econometrica, 50, 4, pp. 987-1007. https://doi.org/10.2307/1912773

[13] Fama, E., French, K. (1993). Common Risk Factors in the Returns on Stocks and Bonds. Journal of Financial Economics, 33, pp. 3-56. https://doi.org/10.1016/0304-405x(93)90023-5

[14] Fu, F. (2009). Idiosyncratic Risk and the Cross-Section of Expected Stock Returns. Journal of Financial Economics, 91, pp. 24-37. https://doi.org/10.1016/j.jfineco.2008.02.003

[15] Gaurinchas, P. (2020). Flattening the Pandemic and Recession Curves. In R. Baldwin and B. W. di Mauro (Eds.), Mitigating the COVID Economic Crisis: Act Fast and Do Whatever It Takes, London, Centre for Economic Policy Research - CEPR Press.

[16] Gujarati, D., Porter, D. (2011). Basic Econometric. $4^{\text {th }}$ Ed. New York, The McGraw-Hill Companies.

[17] Kalra, S. (2008). Global Volatility and Forex Returns in East Asia. International Monetary Fund, IMF Working Paper WP/08/208. Available at https://www.imf.org/external/pubs/ft/wp/2008/wp08208.pdf. https://doi.org/10.5089/9781451870664.001

[18] Khanthavit, A. (2020). World and National Stock Market Reactions to COVID-19. ABAC Journal Vol. 40 No. 2 (April-June). https://doi.org/10.13140/RG.2.2.22792.57606.

[19] Mackellar, L. (2007). Pandemic Influenza: A Review. Population and Development Review, 33, pp. 429451. https://doi.org/10.1111/j.1728-4457.2007.00179.x

[20] Mckibbin, W., Fernando, R. (2020). The Global Macroeconomic Impacts of Covid-19: Seven Scenarios. Available at https://www.brookings.edu/research/the-global-impacts-of-macroeconomic-covid-19seven-scenarios/. https://doi.org/10.2139/ssrn.3547729

[21] Naidenova, I., Parshakov, P., Shakina, E. (2020) .Idiosyncratic and Systematic Shocks of Covid-19 Pandemic on Financial Markets. Available at https://papers.ssrn.com/sol3/papers.cfm?abstract_id=3574774. https://doi.org/10.2139/ssrn.3574774

[22] Pata, U. (2020). Is the Covid-19 Pandemic a Financial Disaster for G7Countries? Evidence from a Fourier Cointegration Test. Available at http://www.researchgate.net/publication/341584345. https://doi.org/10.2139/ssrn.3603068

[23] Rosenberg, B., McKibben, W. (1973). The Prediction of Systematic and Specific Risk in Common Stocks. The Journal of Financial and Quantitative Analysis. 8, pp. 317-333. https://doi.org/10.2307/2330027 
[24] Salles, A. (2006). Evaluation and Seasonality of the Market Risk in Latin América: A Bayesian Approach. in Anales del XIII Congreso Latino-Iberoamericano de Investigación Operativa, Montevideo, Asociación Latino-Iberoamericano de Investigación Operativa (ALIO). https://doi.org/10.1007/bf02888770

[25] Scholes, M., Williams, J. (1977). Estimating Betas from Nonsynchronous Data. Journal of Financial Economics, 5, pp. 341-360. https://doi.org/10.1016/0304-405x(77)90041-1

[26] Şenol, Z., Zeren, F. (2020). Coronavirus (Covid-19) and Stock Markets: The Effects of the Pandemic on the Global Economy. Eurasian Journal of Researches in Social and Economics, 7, Issue 4, pp. 1-16. Available at https://dergipark.org.tr/tr/download/article-file/1077567.

[27] Sharpe, W. (1963). A Simplified Model of Portfolio Analysis. Management Science, January, pp. 277293. http://doi.org/10.1287/mnsc.9.2.277

[28] Shi, H. -L., Zhou, W. -X. (2019). Weekly idiosyncratic risk metrics and idiosyncratic momentum: evidence from the Chinese stock market. Cornell University. arXiv:1910.13115. Available at https://arxiv.org/pdf/1910.13115.pdf. https://doi.org/10.2139/ssrn.3477049

[29] Wooldridge, J. M. (2012). Introductory Econometrics: A Modern Approach. 5th Edition, South-Western Pub, Mason.

[30] Zeren, F., Hizarci, A. (2020). The Impact of COVID-19 Coronavirus on Stock Markets: Evidence from Selected Countries. Bulletin of Accounting and Finance Reviews, 3, pp. 78-84. https://doi.org/10.32951/mufider.706159 